\title{
KTH Royal Institute of Technology
}

\author{
Sepideh Karami
}

Stories we can't tell: on writing dissident architecture

\begin{abstract}
:
Writing architecture is not writing about architecture, but writing it, making it. It is to create new grounds, sites of actions, and construct characters who build these grounds and change them by inhabiting them critically and performatively. By situating writing in contexts where direct ways of expression are impossible, I investigate how dissident writing can circumvent the bans of an oppressive power by inventing an Aesopian language. Dissident writing is to write with multiple voices and many authors - not all of whom are welcome. To develop a tactic of writing with unwelcome co-authors, i.e. writing with the dominant power, but against it, is what dissidence could bring into writing architecture. In this way, writing dissident architecture deals with two main questions. One is: how to tell a story we cannot tell? And the other: how can this struggle with an impossible narration create a dissident architecture? To investigate these questions, in this text domestic spaces of houses are considered as a key example of performing grounds for dissidents. By going through an experiment of writing situated in the spaces of a demolished house, I discuss how the construction of dissident characters who perform in the house and the application of different genres and experimental writings complicate the house and bring on the writing of a dissident architecture.
\end{abstract}

\section{Biographical note:}

Sepideh Karami is an architect, writer and researcher with a PhD from KTH School of Architecture, Critical Studies. Her thesis focused on the idea of Interruption and dissident architecture developed through writing practices and critical fiction understood as political practices of making architectural spaces. She graduated from Iran University of Science and Technology in 2002 with an MA in Architecture, and from Chalmers University in Sweden with an MA in 'Design for Sustainable Development' in 2010. Since completing her first degree in architecture, she has been committed to teaching, research and practice in different international contexts.

\section{Keywords:}

Creative writing - writing architecture - dissidence - censor - Aesopian language ketman - performative writing - domestic spaces - house 
In his essay 'Love, Iranian style', James Wood writes about how novelists 'fret over how to get their characters into and out of rooms, but what if their characters weren't allowed to be in those rooms in the first place?' (Wood 2009). By thinking this way, Wood invites the terms and conditions of censorship into the plot of the story and portrays the bans spatially, as closed doors that prohibit entry. Characters, as such, are kept outside the rooms. But what happens to those characters? Where will those characters wander? Does the writer, under such circumstances, investigate how a character might find a way to enter the closed rooms? Could she find a way to force her characters inside? Or are those rooms left empty?

The metaphor of closed rooms and the impossibility for the characters of entering the rooms while struggling to find a way in is what sets the ground for writing a dissident architecture. In other words, dissident architecture evolves through writing the performative acts of these characters, their inhabitation of these spaces, and how they change these spaces through their 'critical inhabitation' (Karami 2018a: 310). Writing like this is a way of inventing a language that allows those characters to be in those spaces and thereby question, challenge, and subvert the bans that rule over spaces and bodies. Such language could be described through dissidence that is an implicit, slow, and minor mode of political struggle, taking shape not by making an appearance, but through low-key mechanisms and tools, methods and tactics - different from the overt critical gestures applied in mainstream activism - that fool and circumvent an oppressive power structure.

Dissidents have been acting in such impossible situations throughout history, and rather than surrendering the floor to the dominant power entirely and retreating, or entering into inconsequential and dangerous confrontations with those power systems, they have found other ways of challenging the dominant power, perhaps through more tactical engagement, and have thereby created alternative grounds of political action. For example, dissidents of the Soviet Bloc - well documented in the dusk of the communist era - risked their lives by organising underground gatherings, lectures, exhibitions and performances (Weizman 2012: 27). In her text 'Dissident through activism', Ines Weizman compares dissident architects in the Soviet Bloc with the western activists of the time, rendering the latter as those politically engaged in the world, and the former as engaged in 'a mode of retreat from it' (Weizman 2012: 27). Dissidents instead moved into 'the imaginary, ironic, dreamlike and the impossible' as well as into domestic spaces. She writes:

The sites of dissident architecture were the kitchens - private sites of social interaction and production behind a closed door - and the paper - the ultimate site of architectural fantasy - that needed not to be materialized. (Weizman 2012: 27)

Despite such an apparent retreat from the oppressive power and withdrawal to underground activities, dissident architects, as Weizman argues, could challenge the 'standardized language of Soviet architecture', namely through 'paper architecture', and thereby expand their influence on the politics and 'ethical function of various forms of 'creative practices' (http://dissidence.org.uk/synopsis/ 2012).

In my discussion of dissidence, I would like to forward dissidence through tactical and critical engagement with the dominant power rather than retreat and withdrawal from it. As Weizman puts it, because direct confrontation with the dominant power is absent, dissidence is criticized as becoming complicit with power. At the same time, Weizman's term 'momentary complicities' (Weizman 2014: 09) could perhaps describe dissidence as fooling operations rather than complicities. This momentary 
complicity is what I prefer to describe through the act of oscillation between imagination, underground, impossible modes of being, and the confrontation with the dominant power, going in and out of the hegemonic power structure. Such constant oscillation fools an oppressive power and creates a crack in the system, as well as constructs alternative grounds of action and living. In this way, the dissident mode of political engagement, be it in architecture or other forms of practices, is not only about creating a safe haven, shielded from the violence of an authoritarian regime, but also making small and radical changes gradually. ${ }^{1}$ This mode of articulation of dissidence allows us to develop a radical position that is critical from within, a position achieved by projecting an alternative that is examined precisely through living with it over an extended period of time.

This close proximity to the dominant power turns a dissident into a figure who inevitably writes with an unwelcome co-author; that is, she writes with the oppressive power structure. At the same time, she writes against it, covertly or in a subversive manner that is difficult to recognise because its subversiveness is disguised. As it is disguised, it is less likely to be blocked, which means its practice can be prolonged. Dissidence is the art of not being caught while radically challenging the dominant power.

In order to achieve such a precarious political engagement, dissidence becomes a slow process requiring a deep perception of the context, enabled through what I have called 'critical inhabitation' (Karami 2018a: 310). The complexity of the context and the everpresent danger of being caught in such critical contexts necessitate a continuous attention and slowness in action. This mode of political engagement requires a lot of thinking and investigation, and a tireless process of trial and error - in a manner of oscillation - on various scales and at various distances from the context. The slow process and the research-like lifestyle is what induces radicality in dissident methods. It is through such political engagement that I address the practices of writing dissident architecture. What kinds of methods and language should be articulated to develop such architecture? What is the material of such architecture and who constructs it?

\section{Writing dissident architecture}

Writing architecture is not to write about architecture, but to write it, to make it, to make 'something emerge through writing' (Frichot 2010: 313). In her text 'Following Hélène Cixous' steps toward a writing architecture', Hélène Frichot sheds light on the importance of writing practices in architecture that are usually undervalued only 'as a passive after-effect of the built form and not an active force' (Frichot 2010: 312). She writes:

Writing does not arrive after the fact, and reflection here is not a mere representation of a reality assumed to be framed and completed. Writing intervenes and disrupts, turns up the soil of material, the mixtures of bodies, just as it enlivens the incorporeal expressions of sense and nonsense making. (Frichot 2010: 313)

Along with Frichot's take on writing architecture, I situate writing architecture in specific political sites, with impossibilities for direct speech, not to explain what it is or what exists there but what writing could enable in those sites. In other words, writing through them is not about representing stories that have already been told and exist, but injecting new stories, constructing new spaces, producing new material and thereby questioning the dominant relations in place. This act of writing can be explained 
through the performative potential of writing that can introduce new characters into space and thereby produce new spatial relations in architecture sites. The importance of characters as performers in writing dissident architecture accentuates the performative characteristics of writing rather than representational ones. In her Architecture from the outside: Essays on virtual and real space, Elizabeth Grosz writes:

After it is built, structure is still not a fixed entity. It moves and changes, depending on how it is used, what is done with and on it, and how open it is to even further change. What sorts of metamorphoses does structure undergo when it's already there? What sorts of becomings can it engender? These kinds of issues cannot simply be accommodated or dealt with by the plan or blueprint. (Grosz 2001: 06)

One work of writing architecture would be about bringing in these changes that Grosz depicts, which cannot be dealt with through the conventional architecture representational methods, including representational writing that only describes what is there. Architecture work, from the spark of an idea to its final form, intermingles with various stories. These stories might stop or transform, becoming others. New stories might emerge through unexpected events. And this process continues after the architect and the construction team have finished their work; these stories go on and continue the work of architecture. Writing architecture can induce these stories, change them or interrupt them. Therefore, as a practice of architecture, it is an ongoing work of spacemaking and what keeps architecture work unfinished and continuous.

An example from Gianni Celati's short story 'A scholar's idea of happy endings' could expose how writing can transform the dominant fixed relations of a context and bring spaces of hope to people. In his short story, Celati gives us an account of a character who is writing inside the story. The character, who can't 'bear the tragic endings' (Celati 1985: 65) of the stories, rewrites the endings by inserting strips of paper that cover the parts that trigger those tragedies, thus changing them so radically that the story changes its trajectory and moves on to a happy ending. This sort of writing requires a thorough reading of the text in order to bring in changes; in other words, one should inhabit the text, as the context and space of action, to be able to transform it.

This forceful activity of writing in Celati's example is what I forward as the act of writing architecture. Architectural writers, as Marko Jobst writes, are 'the visionaries of material becomings' (Jobst 2016: 64), who write the elements of architecture as well as the relation of performative bodies to them. Dissident architecture writers, however, write through a stealth language that circumvents the probable oppression or blockage and crosses the borders of impossibilities. They drag out hidden performers from architectural sites, shape them, and push them to keep on performing and changing the site.

To develop writing dissident architecture, I situate the act of writing in a context, characterized with complexity and ambiguity, where direct forms of expression are impossible. In other words, there are stories to be told in these contexts, but telling them proves impossible. Here writing dissident architecture deals with two main questions. One is: how to tell a story we cannot tell? And the other: how can this struggle with an impossible narration become materialised and create a dissident architecture? It is in the investigation of these two questions in relation to each other that dissident architecture comes into existence.

One approach to these questions is through methods of complicating spatial relations in (writing) dissident architecture that create complex, ambiguous and labyrinthine spatial qualities. This approach produces a complex system of meanings, signs, 
language, tools, and modes of narration that take shape in response to a dominant system that is obsessed with surveillance and control. Ironically, the system of control itself works with complexity in a multilayered mode; it usually operates through a complex and obscure system of controlling, prohibiting, permitting, segregating, silencing, punishing and rewarding. The system itself has developed on the logic of concealing and stealth; it is an opaque and changing system, oscillating between the realm of law and out of it, in a 'state of exception' (Agamben: 2005). ${ }^{2}$ In this opaque and confusing system, many political collisions would be undertaken in silence and darkness and end in that silence. Dissidents grope about blindly in this darkness and silence, as does the oppressive power.

\section{Censor: A co-author to write with/against}

One strategic instrument of control and prohibition in the hands of the dominant power is censorship. Censorship is not the total ban of a certain activity, but concerns how activities are regulated and curtailed by rules that have been determined. It paradoxically invites the dissidents to participate while simultaneously excluding them from that participation. Censorship points to the ambiguous oscillation of the dominant power in and out of the realm of law, where the boundary between what is permitted and what is prohibited is vague and mutable. By breaking the rules of censorship, the work is automatically condemned to exclusion from public reception. Therefore, that boundary - the line between what is permitted and prohibited - is a performing ground for a dissident, on which she has to walk, like a tightrope walker. The tightrope, however, is moving dramatically under the feet of the dissident, putting her in more danger.

When censorship imposes its rules on a field, that field goes from being a creative or intellectual field to a field of scrutiny. While it clearly demonstrates the might of a dominant power and its instruments of control, it also has blind spots; the process cannot be exhaustive, and it is exactly in these blind spots - perhaps even where the censor has been won over - that dissidents discover a small foothold. The dissidents not only discover such footholds, but also construct them by inventing a new language, through which they fool and circumvent censorship.

In the process of censorship, in the confrontation between the author of the work and the censor, there is an extra element applied as the instrument of scrutiny by the latter. Lev Losseff, in 'On the beneficence of censorship: Aesopian language in modern Russian literature', writes about the censorship of literary texts and the conflict between the censor and the author by considering the text through two different phenomenological aspects. Where the author views her writing as a work of art, the censor reads it as a material object (Losseff 1984: 05). Losseff writes:

Yet because this text is one thing in the political structure and another in the artistic structure, the Censor and Author, while seemingly dealing with the same quantity, are actually dealing with two disparate quantities. (Losseff 1984: 05)

It is in the encounter of these two understandings of the work - in an unequal power relation - that the work necessarily becomes political. That extra element of scrutiny plays an important role in the creation of new methods of creative activity; in different fields, this extra element could be viewed as extra-literary, extra-architectural, etc. It is by means of that extra element that a language could be developed that could blur the distinction between the creative and the political. On the one hand, the censor uses the 
'extra' as a device of investigation and for ticking off items on a checklist to confirm adherence to the dominant values. On the other hand, the author as a dissident should understand how to turn that extra element of scrutiny against itself by inventing a new language that disrupts its logic. This extra element is thus the object of an encounter between the censor and the dissident; a conflict through which the two become coauthors, by writing a text together.

In his novel Censoring an Iranian love story, Shahriar Mandanipour plays with such an idea. The book, which is about censorship, has also been censored by the author in order to receive publishing permission. Wood writes that the novel 'is not simply prohibited by censorship but made by it' (Wood 2009). The story unravels in the impossibility of expressing the affection between two characters who are in love with each other. As Wood brings to our attention, the author's figurative insistence on the impossibility of writing a love story by writing it is what delicately reveals the relationship between the censor and author, transforming a non-literary element into a literary one. In other words, he not only writes about the censorship, he also writes with it. The characters in Mandanipour's novel suddenly leap out of the fictional universe into the real world and have to deal with the rules of censorship. Thus, the border between the real and fiction is blurred. For Mandanipour, the rules of the censorship themselves become that extra element in the novel that makes the novel evolve.

\section{Residing in the shadow: Aesopian language}

In this way, those working under conditions of prohibition and restriction in any field must keep the censor in mind. This, 'at the expense of freedom', does not necessarily harm the creative process, but as Leonidas Donskis writes in his 'Power and imagination: Studies in politics and literature', it nurtures '[a]llegory, fable, political fantasy, or social satire' (Donskis 2008: 146). Donskis suggests that 'ideological censorship' causes Aesopian language to emerge in literature (Donskis cited in Loseff 1984: 04). Lev Loseff maintains that this genre works through elements such as 'allegory, parody, periphrasis, ellipsis, quotation, shifts ('sdvigi'), reduction ad absurdum, and non sequitur', but can also emerge in 'historical fiction, exotica, science fiction, nature writing, anecdotes, translations, and children's literature' (Loseff cited in Rancour-Laferrier 1987: 366). Although 'Aesopian language came to existence in ancient times' (Savinitch 2005: 108), it was first used by the Russian satirist M. E. Saltykov-Shchedrin in his Letters to auntie in the $19^{\text {th }}$ century (Terian 2012: 75). In the words of Lioudmila Savinitch, Aesopian language holds a sort of 'figurativeness', which is different from that of the fable and parable (2005: 108). As she writes: 'Aesopian 'figurativeness' serves to present thoughts that are illegal or in contradiction to official state policies or ideologies' (Savinitch 2005: 108). By differentiating the Aesopian figurativeness from fable and parable, she describes such language as:

[...] an utterance, used strategically, which, by means of various discursive devices, may generate a second semantic level of speech, i.e. a hidden layer, the content of which is officially undesirable or forbidden; in other words, with the implicit content, or subtext, that is officially undesirable or forbidden. (Savinitch 2005: 109)

Savinitch points to a shift in the operation of Aesopian language where it is the subtext that carries the main content, rather than the explicit main text. In this way, Aesopian language is a way of writing in between the lines, saying things without directly expressing them, and creating a situation from which multiple meanings could be understood. 
A friend once told me a true story about a censor whose job was to scrutinise novels and literary texts. His task was basically to read novels through the eyes of a censor, trying to find direct or indirect statements that could signify or hint at something oppositional or subversive. To do such a task, one must have a vivid imagination and the ambition to dig through the layers of a text. Not only did the censor have to read the books, he also had to critically deliberate every single statement and consider the other meanings that it might potentially bear. The close reading of literary texts that his job required is a familiar technique to those from the field of literature. Years of working with texts and practicing close reading made the censor a fan of literature. He gradually lost his power of scrutiny and went off-course in the world of fiction, among the words and in the flow of stories. Consequently, he became a bad censor. He lost his job, but became an expert and lover of literature. This is one of the main powers of dissidence: it is contagious and can turn tyrants into dissidents. These literary texts had been written following the rules of censorship, in order to qualify for a chance to be read by the censor. But the complexity of the applied language drew the censor into the narrative and absorbed him into its multiple layers.

The subtlety and complexity of dissident language creates a chance for dissident literature to be read. If the texts had been written in an overt language of dissent, they would never have been considered from the outset. Yet the use of allegorical language gives the author the chance to be read by the censor, and as a result might even influence the censor to such a degree that $\mathrm{s} / \mathrm{he}$ loses his job and instead discovers a love of literature. A small success story for the dissident project, this shows how dissident methodology can trap conservative minds and create more cracks in the oppressive power structure, but at the same time it can connect to those who might also be inspired to become critics of a political situation, and then dissidents.

\section{House: An Aesopian architecture}

Layered spaces, complex corridors, disguised spaces behind mirrors, hidden staircases, underground labyrinths, closets opening onto staircases, a roof without stairs or ladders, basements and dark storages could be the conceptual and real spaces of dissidence. These spaces are not unrealisable imaginary ones; they could actually exist, they could be built and inhabited through acts of critical inhabitation. Such hidden and stealth spaces emerge in response to oppression and restrictions that otherwise prohibit subversive modes of being. Banned modes of being do not cease to exist, but move to hidden spaces and continue growing in the shadows. They resist proscription by hiding behind themselves, behind their changing and unrecognised characteristics. The space behind a mirror represents such latency; in the mirror, figures of tyranny merely see themselves reflected, and all the while subversive modes of living continue to develop.

Such spaces are activated and constructed by dissidents' critical inhabitation while hiding in them. In her Performing ground: Space, camouflage, and the art of blending in, Laura Levin explains the concept of camouflaging not as being invisible, but as becoming visible differently (Levin 2014). In a discussion of dissidence, the process of camouflaging can be read as constructing an identity capable of fooling the dominant power, or essentially, ketman. Ketman ${ }^{3}$ is a 'covert dissent' (Donskis 2008: 146), a concept through which people's real thoughts are kept as a subtext rather than being expressed explicitly. As a tactic for living under oppressive regimes, it allows the dissident to reside in the cracks of those systems without deferring to their values or obeying their rules. 
In his book The captive mind, Czesław Miłosz writes about various forms of ketman. For example, in 'Aesthetic ketman', he talks about 'a man of taste' who applauds and writes supportive reviews of propaganda art exhibitions and the like in public, and ' $[\mathrm{h}] \mathrm{e}$ changes completely within the four walls of his home' (Miłosz 1955: 61), listening to different music, collecting different art and writing differently.

Although this reading of ketman points to the individual freedom one could achieve in his/her private realm, I argue that this individual freedom must also be used toward the invention of a language that could challenge the dominant power. If the dissident withdraws to the 'four walls of home' and turns the home into a site of dissent, there should be a process that allows the dissident to retaliate against what has pushed him or her into that private realm; the dissident must be able to exit her house, or somehow let her thoughts leak out, perhaps as a political act, lest the house become a prison. Such an approach requires the use of subversive language, even when one appears to be writing supportive propaganda. In this reading, ketman becomes a concept that expands the scope of politics from the public sphere to the private and domestic spaces of life, but it can also prepare the conditions for an expansion of politics, whereby dissidence leaks through the 'four walls of home' into the public sphere. Ketman becomes a tactic with the potential to open up a space for the dissident to speak to power without being oppressed or falling into danger, specifically by means of an Aesopian language.

In narrating political stories, the domestic spaces of the houses could work through Levin's concept of camouflage, or as I forward it, through ketman. The house, understood as a performing ground for dissidents, both protects them and makes it possible for them to develop their dissident tactics. It can work as a mask, protecting their identities while letting them practise their subversive acts. Furthermore, as in the above story of the censor, the house could also work to produce what could later make others outside of the house dissidents. Nevertheless, the domestic spaces of the house are not totally detached from the politics of the outside. In his The politics of small things, Jeffrey C. Goldfarb pictures the kitchen tables where 'friends and relatives are relatively free to discuss narratives of their lives that are distinct from the official truth' (Goldfarb 2006: 13). Yet they are aware that when they move away from this table, things are different. He writes: 'while power does not directly intervene in these interactions among friends and family, it is present. It controls even what is articulated against the powers' (Goldfarb 2006: 13-14). The presence of power, even in the domestic spaces of the home, trains the dissidents to articulate a language that could be later applied when speaking to that very power, in exactly the same manner as the writer writes with the censor as her or his co-author.

\section{Writing a dissident house}

Dissident architecture as I forward it starts from the performative aspect of dissidence; i.e. how dissidents inhabit spaces and change the spatial relations through their inhabitation. Situating such inhabitation in the domestic spaces of a house, I undertook a writing experiment in 2017 as part of my PhD thesis, called 'The house, the wings, the balcony, the dissidents', where I tried to develop an Aesopian language in architecture through writing a house of dissidents (Karami 2018b: 257-296). 


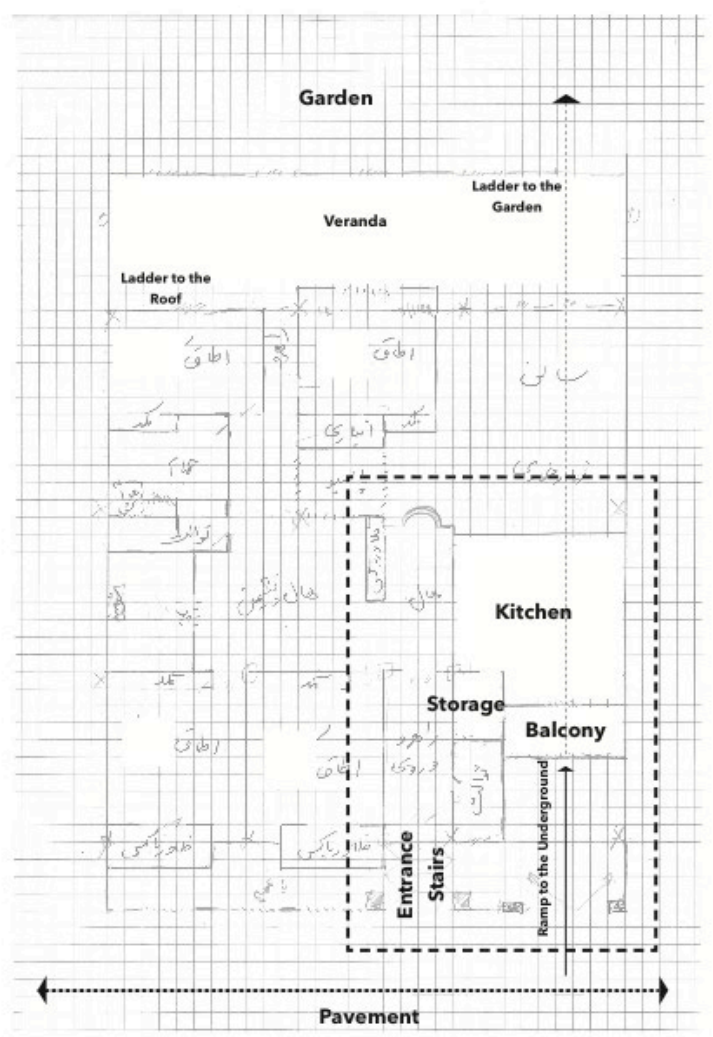

Figure 1. The house plan drawn by the inhabitants of the house

In this experiment, the story of the house resided in a hand-drawn plan, drawn from memory by the inhabitants of a demolished house. The house is real, and its real architectural plans were lost following its demolition. The house was built in a critical time of war and revolution and had undergone different phases of inhabitation. The text is written through layers of writing as sketching on hand-drawn plans. The acts and stories have emerged through the re-writing of spaces and their relation to the contextual politics of the place. The text consists of different layers that extend the spaces of the house, multiply it, mirror it, stretch it beyond its walls, complicate its relations. They animate its elements, re-erect its demolished walls, windows, and doors and revitalise the stories embedded in each and every element.

To write this house of dissidents, I used a writing method that operates between fiction, playwriting, conversation, poetry, essay and other, experimental forms of writing. The aim with these genres was to write an architecture that is not a mute object, but the site of actions, voices, smells, and moving human and nonhuman elements. This architecture consists of parts and elements that disappear, fall and reappear. 
The House, The Wings, The Balcony,

The Dissidents

\author{
The Characters: ${ }^{5}$
}

I: Who narrates

He: Who draws the plans

She: Who recalls the story

She: Who has the luggage

He: Who grows, who dreams, who falls

Figure 2: The design of the characters in the house of dissidents

In writing the dissident house, the characters were the main elements for making a dissident architecture. These characters however are not introduced by how they are, but are constructed by what they do (Figure 2). Sergei Tret'iakov in 'The biography of the object' accentuates the role of literature, suggesting that it should provide us with 'deed' rather than with 'people'. In development of the biography of the object, he eliminates the role of the hero that is common in the traditional novel, and instead casts attention on the 'act' undertaken by the characters (Tret'iakov 2006: 58). Following Tret'iakov, the characters in the house are always in change and disappearing behind the architectural elements of the story. I followed the characters' actions, transformations, movements, and inhabitations by writing them, making them, inventing them. As I wrote them and their acts, they came into existence. I constructed various characters that critically inhabit the house, interrupt its existing established relations, construct performing grounds, and thereby become dissidents. These characters in the house are fluid identities, shadowy and messy, who escape definitions and representations. They are unfinished and incomplete, in that in contrast to the supposed psychological complexity of the western bourgeois characterization, we don't really get to know them in full, but in bits and pieces. These pieces invite us to put them together as if a jigsaw puzzle. They transform from one to another through performing radical projects, becoming one and many, and create a multitude of minor political performers; they speak with each other's voices, constructing a 'plural I' (Minh-ha cited in Pelias 2014: 14) that does not reduce the many voices to one, but complicates one's own voice by including the voices of others.

By accentuating the role of characters in the house and through a performative lens I analogize the house to the spaces of theatre. The play in this theatre space is the act of dissidence. The performers of this play are not only the inhabitants of this house, but also the architects of its spaces, making space by living in it, by playing in the house, destroying and reconfiguring the spaces, hiding in niches and whispering through the cracks. The house is initially understood as the backstage of street politics, when the stage, the street, the square, becomes an impossible place to perform. At times the 
backstage is the space of anticipation, and at other times an empty space. Yet this backstage itself is imagined as a complete theatre space, consisting of its own stages, wings and backstage; a theatre inside a theatre. The kitchen, storage and basement are the wings of this theatre space. Characters wait there, repeat their lines in anticipation and leap onto the micro-stages, onto the balcony, stairs, ladders, rooftop, exposing a dissident performance, yet covert and in the manner of ketman. In this way, the house lets the acts leak out through fragmented and evanescent micro-stages.

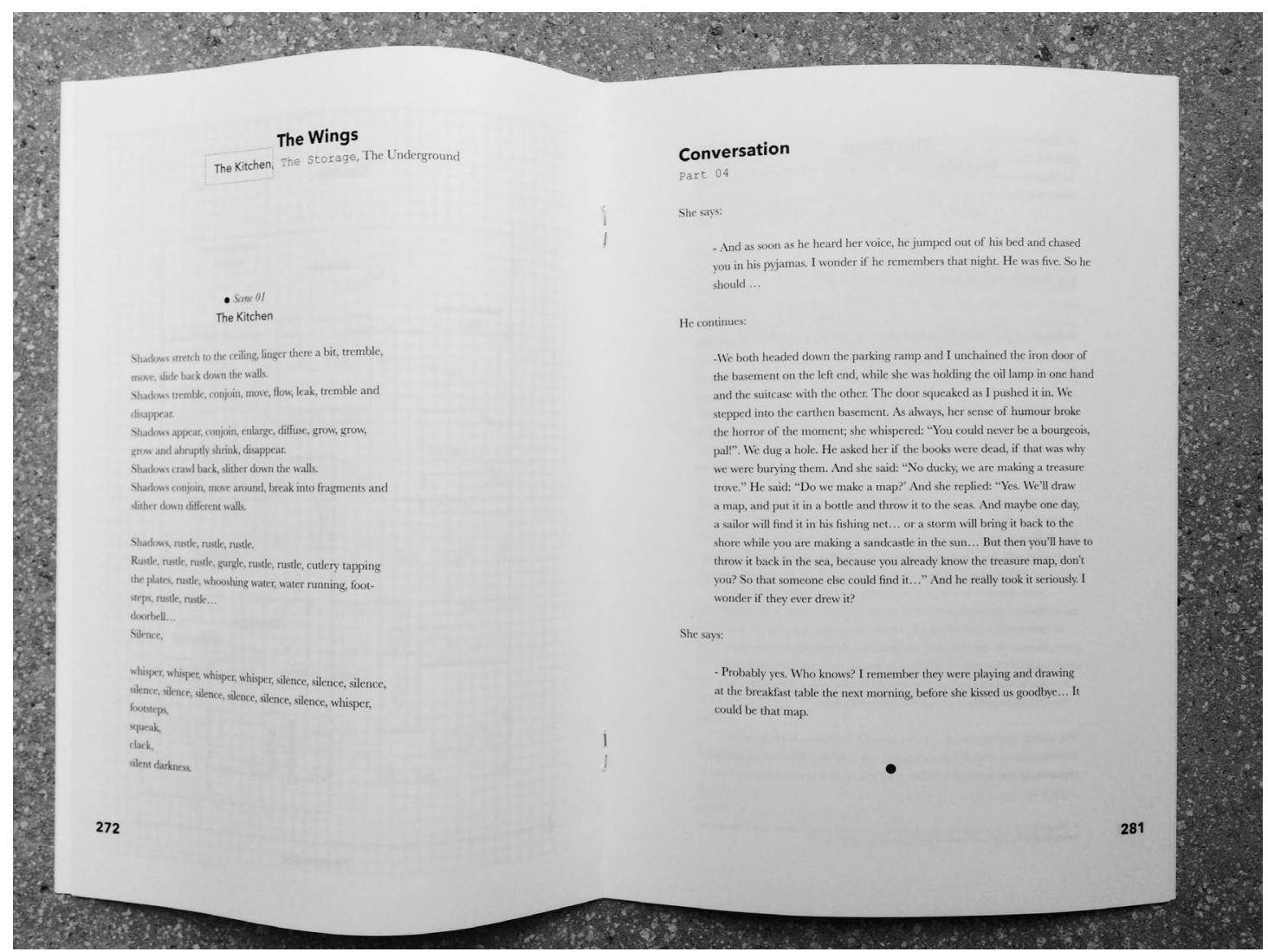

Figure 3: Conversation between $\mathrm{He}$ and She while they draw the house plan from memory

The characters are moved around these stages and wings by various forms and experiments of writing such as fictional conversations, interrupted by the stories, scenes, secrets, poems, lists, puzzles and manuals. In other words, the spaces of the house are constructed by these pieces of writings. Parts of the text that are written through a conversation set up stages for the character, for example. In her dialogue with Klaske Havik, Katja Grillner says that dialogue could 'bring characters from different places and times into a temporary fictional location' (Grillner \& Havik 2016: 159). Each part of the conversations thus opens up a memory, a space for re-writing the architecture of the house, a space in which a new character comes to the stage and starts performing while constructing the spaces of the house. With the appearance of the character in every single space, the space is re-constructed. The dialogue stops for the character to perform on that stage, reconstruct the space and then disappear into the space of dialogue, reappearing at a later point in the conversation. 


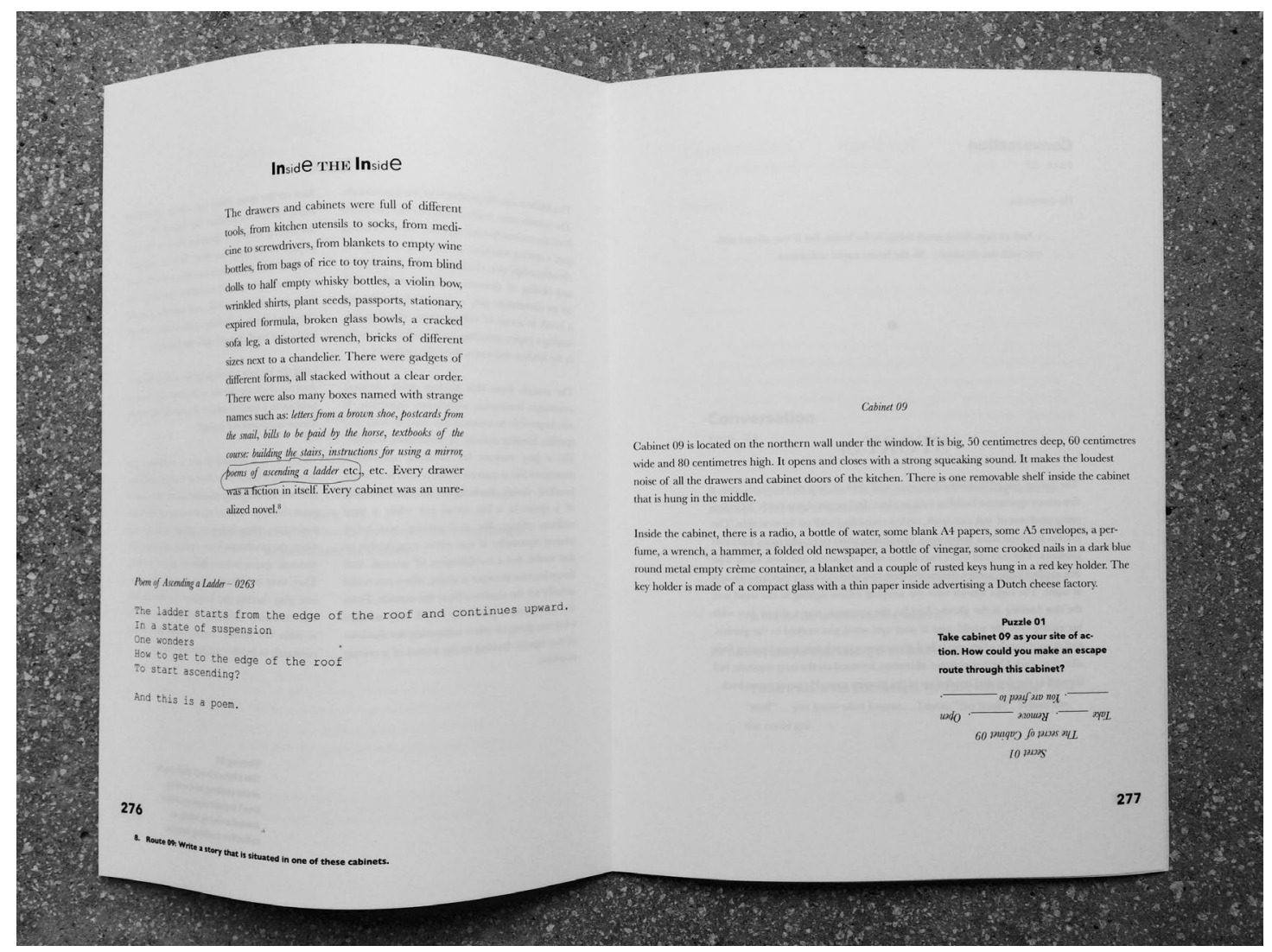

Figure 4: The combination of list writing, poem, puzzle and secrets

In every pause of the conversation and every appearance of characters in different wings and stages, various genres and experiments are applied to construct the space and further the acts of the characters. For example, list writing is an applied genre in this text that complicates the spaces, expands them, adds more layers, and creates different relations between the spaces. The cabinets and drawers in the kitchen are the main containers of this list writing. List writing transforms the cabinet from a mere storage space to a site of making, or a factory for producing stories and ideas. The accumulation of different and seemingly unrelated elements in a single cabinet creates a world, or could motivate the readers to create various worlds by those elements. In this way, every drawer becomes a fiction in itself. Every cabinet becomes an unrealised novel. A cabinet - which is a physically limited space - expands beyond its limits and the characters use the elements to further the construction of the house through poems, secrets, puzzles and more.

These genres and experiments also invite the reader to engage more actively with the characters in the construction of the house. Instructions or manuals, secrets and puzzles, for example, invite the reader to inhabit the house and be part of its construction. In one experiment, 'How to move a story from one plot to another', instruction is used to make a turn inside the story itself (Figure 5). To shift the focus from the kitchen to the storage as a shift in the political ground of action in the house, the step-by-step instructions tell the reader how to move from one place to another, thereby introducing certain aspects of dissident performance, such as how to use a blue light to avoid shadows when the characters enter the storage. This instruction acts on various layers: as a move from one physical space to another, as a shift in the locus of the story, and as a shift in the theoretical discussion of the politics of activism to dissidence. 


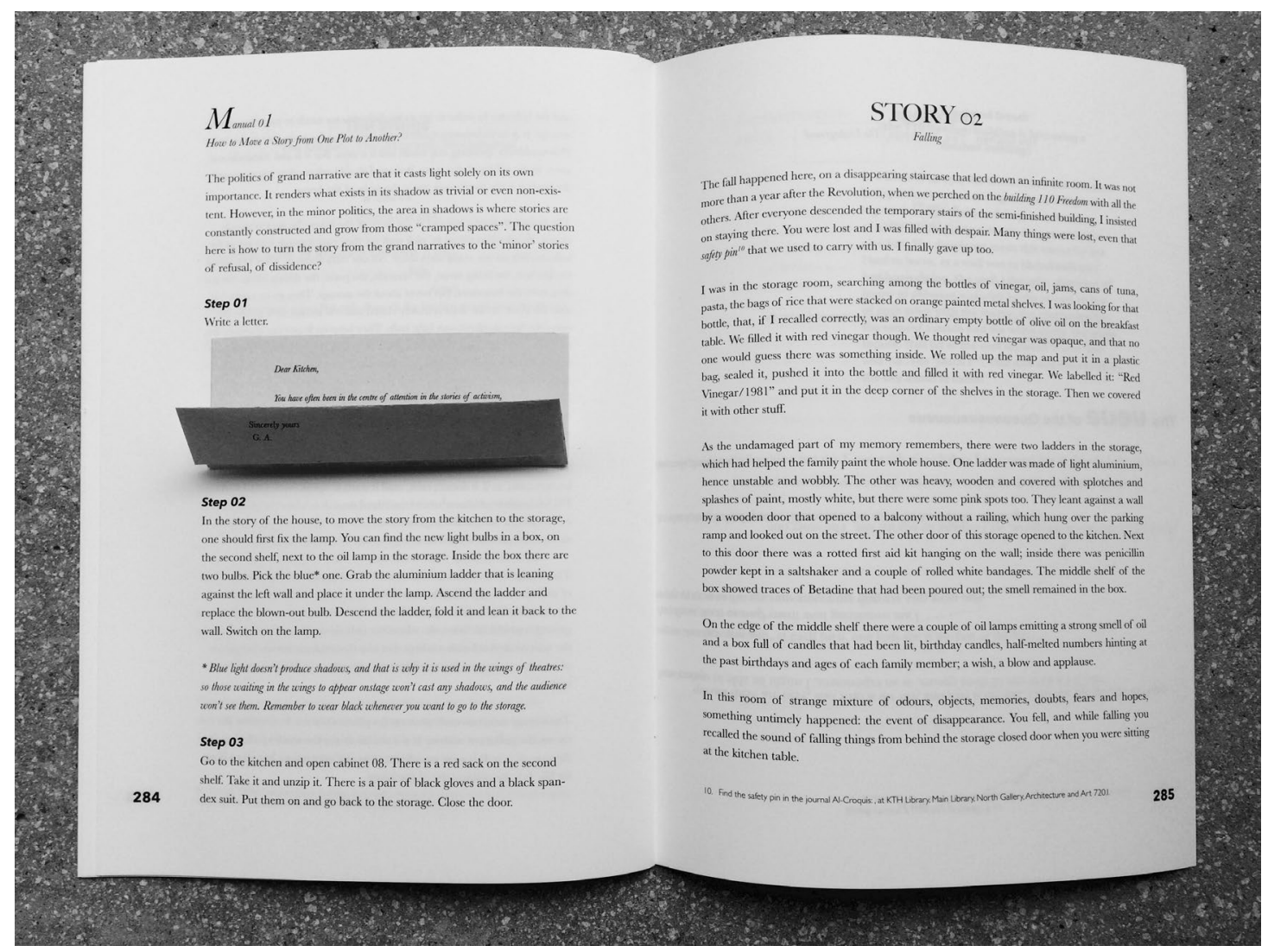

Figure 5: An example from the manual, How to move a story from one plot to another?

The construction of the house is carried out through the architectural sequences of the text. Similar to the drawers of the cabinets in the kitchen, the text could be opened and reopened and could expose more stories - hidden and unknown ones - and mysteries. Each cabinet, each space, each corner, each detail holds a story, meaning that this written story is just one possible story among many. This writing method created a new house within the original house by complicating its spatial relations. This complication is achieved through the retelling of its stories, the activation of its latent layers, cutting through the house, planting unusual plants, moving within the house, expanding some spaces vertically and others horizontally, animating objects, enlarging closets and cabinets, connecting certain spatial elements to the city outside, breaking the linearity of the history of the house and merging the characters with each other. Via writing, the house is connected to the city through the political engagement of its inhabitants. The inhabitants, the dissidents, move constantly between the spaces of the house and the city.

Thus, in this experiment, the complexity and impossibility of exposing the details of a dissident life are revealed in the structure of the text through the method of narration and different modes of writing, and thereby through the complication of a simple house. It is an architecture that cannot be built from a blueprint or a detailed drawing, but that could be lived and acted by responding to various situations, spatial limits and political bans.

The story of dissidents or dissident places can hardly be written at all; that is to say, if the real story were told, the dissident would be vulnerable to danger, or s/he would no 
longer be dissident. Yet the house as the spatial manifestation of ketman could be a performing ground for dissidents, where their stories could be told by writing its architecture. For the stories that we cannot tell, there are ways of performing, of making its spaces, of letting it hide and appear in its spaces in an oscillating manner.

\section{Notes}

1. This way of understanding dissidence could also overcome the worries about which Ines Weizman writes as the inefficiency of dissidence in changing the power relation that it tries to escape: 'On the one hand they appear to be always part of a certain Faustian pact that embraces both dissident and agents of power in a complex relationship that requires momentary complicities that need to be carefully negotiated against the potential effectiveness of gestures of refusal and critique. On the other, dissident acts seem to reproduce the same power relation they had tried to escape' (Weizman 2014: 09) 2. State of exception refers to Giorgio Agamben's concept of the term; he defines it as the unusual extent of power beyond the law that entitles the power to execute its instruments of oppression wherever it benefits its stabilisation, without reference to the question of democracy. He argues that in contemporary western politics - namely after $9 / 11$ - this sort of political performance transformed from an exception to the norm.

3. Ketman is rooted in the Persian language and culture, and it has historically worked against authoritarian regimes. Although it is of Islamic origin, emerging when and where people were forced to hide their faith in the face of danger, it can be applied extensively. Initially a religious strategy used when a man of faith could not express his beliefs, it has been practised in many other contexts under authoritarian regimes and is well documented in the Eastern European context. Ketman, as Donskis writes, can be applied in any 'trans-ideological and trans-civilizational idiom that operates equally well within religious and secular ideocracies' (Donskis 2008: 141).

* This text is a re-worked version of parts of my $\mathrm{PhD}$ thesis, Interruption: Writing a Dissident Architecture, presented at KTH Royal Institute of Technology, Stockholm, in April 2018. The thesis can be found at this address:

http://kth.diva-portal.org/smash/record.jsf?pid=diva2\%3A1191313\&dswid=2450

\section{Works cited}

$9^{\text {th }}$ International AHRA Conference, Architecture and the paradox of dissidence, (15-17 November 2012), at http://dissidence.org.uk/synopsis/ (accessed 30 August 2017)

Agamben, Giorgio 2005 State of exception. Kevin Attell (trans.), Chicago \& London: The University of Chicago Press

Celati, Gianni 1985 Voices from the plains, London: Serpent's Tail

Donskis, Leonidas 2008 Power and imagination: Studies in politics and literature. New York: Peter Lang Inc., International Academic Publishers

Frichot, Hélène 2010 'Following Hélène Cixous' steps toward a writing architecture', Architectural theory review $15(3), 312-23$

Goldfarb, Jeffrey C. 2006 The politics of small things: The power of the powerless in dark times. Chicago \& London: The University of Chicago Press

Grillner, Katja. \& Havik, Klaske 2016 'Between sites and stories, between texts and times: A dialogue about fiction and narrative in architectural inquiries, In Havik, K. et al. (eds.) Writingplace:

Investigation in architecture and literature, Rotterdam: nai010publishers

Grosz, Elizabeth 2001 Architecture from the outside: Essays on virtual and real space, Massachusetts: The MIT Press 
Jobst, Marko 2016 'Writing sensation: Deleuze, literature, architecture and Virginia Woolf's The Waves', The Journal of architecture 21(1), 55-67

Karami, Sepideh 2018a 'Critical inhabitation: Interruption and performative criticality', In Frichot, H. \& Sandin, G. (eds) After effects: Theories and methodologies in architectural research, Barcelona/ New York: Actar

Karami, Sepideh 2018b Interruption: Writing a dissident architecture, Stockholm: KTH Royal Institute of Technology

Levin, Laura 2014 Performing ground, space, camouflage, and the art of blending in London: Palgrave Macmillan

Losseff, Lev 1984 On the beneficence of censorship: Aesopian language in modern Russian literature, Köln: Hermitage

Miłosz, Czesław 1955 The captive mind, New York: Vintage Books

Pelias, Ronald J. 2014 Performance: An alphabet of performative writing, London and New York: Routledge

Rancour-Laferrier, Daniel 1987 'On the beneficence of censorship: Aesopian language in modern Russian literature (=Arbeiten und Texte zur Slavistik, 31) by Lev Loseff’ , Russian language journal / Русский язык 41(138/139), 365-68

Savinitch, Lioudmila 2005 'Pragmatic goals and communicative strategies in journalistic discourse under censorship', In E. Grillo (ed.), Power without domination: Dialogism and the empowering property of communication, Amsterdam/Philadelphia: John Benjamins

Terian, Andrei 2012 'The rhetoric of subversion: Strategies of "Aesopian language" in Romanian literary criticism under late communism', Slovo 24(2), 75-95

Tret'iakov, Sergei 2006 'The biography of the object', October magazine, ltd and Massachusetts Institute of Technology 118, 57-62

Weizman, Ines 2012 'Dissidence through architecture', Perspecta 45: Agency, 27-38

Weizman, Ines 2014 'Dissidence through architecture', Architecture and culture, 2(1), 06-11

Wood, James 2009 'Love, Iranian style: A new novel pits passion and repression.' The New Yorker at https://www.newyorker.com/magazine/2009/06/29/love-iranian-style, 29 June (accessed 14 April 2012) 